\title{
Slab inputs control the isotopic variability of continent-forming arc magmas
}

\author{
JULIEN CORNET ${ }^{1}$, OSCAR LAURENT ${ }^{2}$, JÖRN-FREDERIK \\ WOTZLAW ${ }^{3}$, JUAN ENRIQUE OTAMENDI ${ }^{4}$, GEORGE W. \\ BERGANTZ $^{5}$ AND OLIVIER BACHMANN ${ }^{3}$ \\ ${ }^{1}$ ETH Zurich \\ ${ }^{2}$ CNRS-Géosciences Environnement Toulouse \\ ${ }^{3}$ ETH Zürich \\ ${ }^{4}$ Universidad de Rio Cuarto - Conicet \\ ${ }^{5}$ University of Washington \\ Presenting Author: julien.cornet@erdw.ethz.ch
}

From their source in the mantle to eruption at the surface, convergent margin magmas follow a complex path involving the recycling of pre-existing crust either at mantle depths ("source" contamination) and/or en-route to the surface ("path" contamination). These two mechanisms have fundamentally different implications for crustal growth versus recycling in subduction zones. However, due to limited access to mantle and deep crustal exposures, the roles of "path" and "source" contamination are usually interpreted on the basis of indirect, often ambiguous geochemical data from volcanic and/or shallow plutonic rocks. Here, we present a case of "source" contamination from an Ordovician magmatic series, the Famatinian continental paleo-arc (Argentina), sampled at all paleo-crustal depths and distributed along a $\sim 600 \mathrm{~km} \mathrm{~N}-\mathrm{S}$ transect that formed during an $8 \mathrm{Myr}$ long peak magmatic event (474466Myrs; from high-precision $\mathrm{U} / \mathrm{Pb}$ zircon dating). Bulk-rock and zircon geochemistry show that all samples belong to a cogenetic differentiation suite. However, zircon Hf-O isotope ratios vary from mantle- to crustal-dominated along the arc transect. These variations cannot be explained by "path" contamination as the nature of the local crust does not change along strike and the most crustal isotopic ratios are unexpectedly carried by the deepest and less differentiated rocks. Rather, the isotopic variations correlate with the thickness of sediments entrained in the source with the paleo-slab at the different latitudes. We propose that overlooking the dominant role of crustal recycling by sediment subduction in the mantle sources of arc magmas can lead to significantly under-estimating continental growth in models based on global zircon O-Hf isotopic variations over geologic time. 